\title{
ANALISIS PENERAPAN SISTEM MONITORING PEMASOK
}

\author{
ANALYSIS OF IMPLEMENTATION THE SUPPLIER MONITORING SYSTEM \\ Dahliyah Hayati ${ }^{1)}$, \\ 1) Politeknik APP Jakarta, Jl. Timbul No. 32 Cipedak, Jakarta selatan, 12630, Indonesia
}

\begin{tabular}{|c|c|}
\hline ARTICLE INFORMATION & A B S T R A C T \\
\hline $\begin{array}{l}\text { Article history: } \\
\text { Received: October 29, } 2019 \\
\text { Revised 1: November 12, } 2019 \\
\text { Accepted: March 02, 2020 }\end{array}$ & $\begin{array}{l}\text { The performance of suppliers both directly and indirectly determines several critical points } \\
\text { for the company such as: product prices, product availability in the market, and product } \\
\text { quality. It is very important for companies to monitor and improve the quality of raw } \\
\text { materials obtained from suppliers, because this will determine the performance of the } \\
\text { company, especially on the quality of products produced. The quality monitoring system } \\
\text { implemented in the company must be responsive and consider every critical aspect of the } \\
\text { non-conformity that occurs, not only using the Supplier Correction Action Request (SCAR) }\end{array}$ \\
\hline $\begin{array}{l}\text { Keywords: } \\
\text { Monitoring System Design } \\
\text { Supplier monitoring } \\
\text { Quality Management }\end{array}$ & $\begin{array}{l}\text { Preventive Action Request (SCPAR) form for all types of non-conformity found. In this } \\
\text { study, samples were taken at } 3 \text { different companies in order to obtain valid data to analyze } \\
\text { and evaluate the existing quality monitoring system to get a new quality monitoring system } \\
\text { that more responsive to avoid repeated findings occur. The research method was } \\
\text { conducted by classifying non conformity types based on the level of criticism using the } \\
\text { Total Quality Management (TQM) approach, fishbone diagrams, Failure Mode and Effect } \\
\text { Analysis (FMEA), and Quality Function Deployment (QFD) so that the quality monitoring } \\
\text { system produced is more accurate, effective and efficient in handling raw material non- } \\
\text { conformities that occur. }\end{array}$ \\
\hline
\end{tabular}

\section{A B S T R A K}

Kata Kunci:

Desain Sistem Monitoring

Monitoring Pemasok

Manajemen Mutu

${ }^{*}$ Corresponding Author
Dahliyah Hayati
E-mail: dahliyah.miner@gmail.com

Kinerja pemasok baik secara langsung maupun tidak langsung ikut menentukan beberapa point kritikal bagi perusahaan seperti: harga produk, ketersediaan produk di pasar, dan kualitas produk. Sangat penting bagi perusahaan untuk memonitor dan meningkatkan kualitas bahan baku yang diperoleh dari pemasok, karena hal ini akan menentukan performa bagi perusahaan terutama terhadap kualitas produk yang dihasilkan. Sistem monitoring kualitas yang diterapkan di perusahaan harus responsif dan mempertimbangkan setiap aspek kritikal ketidaksesuaian yang terjadi, tidak bisa hanya menggunakan Supplier Correction Action Request (SCAR) form atau Vendor Corrective Action Request (VCAR) form atau Supplier Corrective and Preventive Action Request (SCPAR) form untuk semua tipe non conformity atau ketidaksesuaian yang ditemukan. Dalam penelitian ini, dilakukan pengambilan sampel di 3 perusahaan yang berbeda dengan tujuan agar didapatkan data valid guna menganalisis mengenai sistem monitoring kualitas yang telah ada saat ini dan mengevaluasi untuk mendapatkan sistem monitoring kualitas baru yang lebih responsif sehingga tidak terjadi lagi temuan berulang. Metode penelitian dilakukan dengan mengklasifikasikan tipe non conformity berdasarkan tingkat kritikalnya menggunakan pendekatan Total Quality Management (TQM), penggunaan fishbone diagram, Failure Mode and Effect Analysis (FMEA), dan Quality Function Deployment (QFD) sehingga sistem monitoring kualitas yang dihasilkan lebih akurat, efektif dan efisien dalam penanganan ketidaksesuaian bahan baku yang terjadi.

This is an open access article under the $\underline{\mathrm{CC}-\mathrm{BY}}$ license.

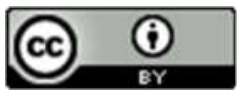




\section{PENDAHULUAN}

Pemasok merupakan salah satu bagian yang sangat penting dalam rantai pasok yang mendukung ketersediaan bahan baku untuk proses produksi perusahaan. Kinerja pemasok baik secara langsung maupun tidak langsung ikut menentukan beberapa point kritikal sebuah perusahaan, seperti harga produk, ketersediaan produk di pasar, dan kualitas produk[1][2]. Dalam penelitian Supplier Development: Theories and Practices [3] diungkapkan bahwa evaluasi menggunakan tiga kriteria yaitu on time delivery, quality(defect per million), dan total cost. Untuk mengevaluasi kinerja pemasok, Parker Hannifin Corporation menggunakan kriteria tersebut.

Tabel 1. Parker Hannifin Corporation Status Tindak Lanjut [7]

\begin{tabular}{|c|c|}
\hline Status & Tindak Lanjut \\
\hline Penting & $\begin{array}{l}\text { Memenuhi persyaratan } \\
\text { yang dibuat oleh Parker }\end{array}$ \\
\hline Lebih disukai & $\begin{array}{l}\text { Kepuasan; Tidak } \\
\text { memerlukan tindakan }\end{array}$ \\
\hline Marginal & $\begin{array}{l}\text { Tindakan perbaikan yang } \\
\text { sistematis mungkin } \\
\text { diperlukan }\end{array}$ \\
\hline $\begin{array}{c}\text { Tidak bisa } \\
\text { diterima }\end{array}$ & $\begin{array}{l}\text { Tindakan perbaikan yang } \\
\text { sistematis diperlukan untuk } \\
\text { memenuhi persyaratan } \\
\text { Manajemen Parker }\end{array}$ \\
\hline
\end{tabular}

Supplier Corrective Action Request (SCAR) pada Parker Hannifin Corporation dibuat lebih rinci ketika adanya permasalahan terkait dengan kualitas dari material yang dikirim (Tabel 1). Parker Hannifin Corporation membagi status temuan ketidaksesuaian menjadi 4 status, yaitu: Penting, Lebih disukai, Marginal, Tidak bisa diterima. Dalam penelitian Evaluation of Supplier Performance [4][1][5], dihasilkan rancangan Supplier Evaluation Model dengan menggunakan evaluasi kriteria quality, delivery, and cost performance (Tabel 2). Penelitian ini berujung pada memetakan fungsi represntatif yang bertanggung jawab jika terjadi suatu permasalahan yang dihadapi perusahaan. Dalam Supplier Quality Requirement Manual dari perusahaan Parker Hanifin Corporation, pemasok harus menjaga sistem mutu dengan sertifikasi ISO dan mengembangkan konsep Failure Mode and Effect Analysis (FMEA) [6][2] untuk mengindari permasalahan kualitas di proses pemasok. Perusahaan Parker Hanifin Corporation memberikan persyaratan bagi para pemasok
(Tabel 3) jika ditemukan ketidaksesuaian pada material yang dikirimkan.

Beberapa penelitian yang telah dilakukan dalam membuat alat evaluasi kerja [8][1][5] atau pedoman untuk meningkatkan kinerja pemasok dengan menggunakan kriteria pengiriman tepat waktu, mutu (cacat per juta), dan total biaya baik digunakan untuk evaluasi maupun untuk pengembangan. Penelitian ini melihat sisi kualitas tidak cukup dilihat hanya dari sisi jumlah cacat yang terjadi namun perlu diteliti lebih jauh mengingat beberapa hal lain terkait kualitas, yang mana cukup berpengaruh terhadap keberlangsungan bisnis perusahaan.

Beberapa penelitian yang membuat kategori pengembangan sistem yaitu:

- Manual Persyaratan Mutu Pemasok dari perusahaan Parker Hanifin Corporation, perusahaan melakukan pengembangan sistem berdasarkan efektifitas Supplier Corrective Action Requirement (SCAR) dengan membagi menjadi empat status: penting, lebih disukai, marginal dan tidak bisa diterima. [7]

- Supplier Development: Theories and Practices [5][9] mengacu pada profil Pemasok, modal dan waktu serta membagi pengembangan menjadi tiga yaitu dasar, moderat dan terdepan.

- Evaluasi Kinerja Pemasok [5][1] memetakan fungsi representatif yang bertanggung jawab jika terjadi suatu permasalahan yang dihadapi perusahaan.

Pada penelitian-penelitian terdahulu belum dibahas secara lebih detail pembagian kriteria ketidaksesuaian sehingga masih terjadi pengulangan-pengulangan ketidaksesuaian. 
Tabel 2 Tabel Evaluasi Pemasok Berdasarkan Kinerja [4]

\begin{tabular}{|c|c|c|c|}
\hline $\begin{array}{c}\text { Dimensi, Kriteria dan } \\
\text { Ruang Lingkup }\end{array}$ & $\begin{array}{c}\text { Frekuensi } \\
\text { (Time horizon) }\end{array}$ & Metode & $\begin{array}{c}\text { Orang yang Terlibat } \\
\text { (Departemen) }\end{array}$ \\
\hline $\begin{array}{l}\text { Module Kinerja Mutu } \\
\text { - Fungsi, geometri, penampilan } \\
\text { dan fitur modul suara pada } \\
\text { dan setelah saluran } \\
\text { - Proses dan struktur Mutu } \\
\text { di dalam modul pemasok } \\
\text { - Pada sisi pemasok dalam } \\
\text { hubungan dengan Volvo }\end{array}$ & $\begin{array}{l}\text { Ketika muncul } \\
\text { cacat pada } \\
\text { mutu } \\
1-2 \text { kali / } 2 \\
\text { tahun (orientasi } \\
\text { masa depan) }\end{array}$ & $\begin{array}{l}\text { Formal, } \\
\text { kuantitatif dan } \\
\text { kualitatif } \\
\text { Semi-formal, } \\
\text { kuantitatif dan } \\
\text { kualitatif } \\
\text { Formal }\end{array}$ & $\begin{array}{l}\text { Operator Perakitan (Perakitan) } \\
\text { QA-engineers (Perakitan) } \\
\text { SQA-engineers (Logistik) } \\
\text { SQA-engineers (Logistik) } \\
\text { Assembly managers (Perakitan) }\end{array}$ \\
\hline $\begin{array}{l}\text { Kinerja Ketepatan Pengirima } \\
\text { - Modul pengangkutan tepat } \\
\text { wakti di loading dock } \\
\text { - Modul pengangkatan box } \\
\text { yang benar pada antrian } \\
\text { - Jumlah batasan pada } \\
\text { rencana Volvo } \\
\text { - Proses dan struktur } \\
\text { Logistik: } \\
\text { - Pada modul pemasok } \\
\text { - Pada sisi pemasok yang } \\
\text { berhubungan terhadapa } \\
\text { interaksi dengan Volvo } \\
\text { Kinerja Biaya } \\
\text { - Modul Harga } \\
\text { - Proses dan struktur : } \\
\text { - di dalam modul pemasok } \\
\text { - pada sisi pemasok } \\
\text { - kontribusi pemasok } \\
\text { - Biaya Logistik: } \\
\text { - Proses and struktur } \\
\text { dalam hubungan dengan } \\
\text { sistem logistik } \\
\text { menyeluruh }\end{array}$ & $\begin{array}{l}\text { 1-2 kali / jam } \\
1 \text { kali / menit } \\
\text { Per kejadian } \\
\text { Ketika } \\
\text { penyimpangan } \\
\text { pengiriman terjadi } \\
\text { 1-2 kali / } 2 \text { tahun } \\
\text { (orientasi masa } \\
\text { depan) }\end{array}$ & $\begin{array}{l}\text { Formal, } \\
\text { kuantitatif } \\
\text { Formal, } \\
\text { kuantitatif } \\
\text { Formal, } \\
\text { kuantitatif } \\
\text { Semi-formal, } \\
\text { kuantitatif dan } \\
\text { kualitatif } \\
\text { Formal, } \\
\text { kuantitatif dan } \\
\text { kualitatif }\end{array}$ & $\begin{array}{l}\text { Pengontrol pengiriman (Logistik) } \\
\text { operator Perakitan (Perakitan) } \\
\text { Pengontrol pengiriman (Logistik) } \\
\text { Pengontrol pengiriman (Logistik) }\end{array}$ \\
\hline $\begin{array}{l}\text { Kinerja Keseluruhan } \\
\text { - Mutu - Manajemen } \\
\text { - Pengiriman - Mjm. } \\
\text { Pemasok } \\
\text { - Biaya - Lingkungan }\end{array}$ & $\begin{array}{l}\quad>1 \text { kali } / 2-4 \\
\text { tahun } \\
\text { (orientasi masa } \\
\text { depan) }\end{array}$ & $\begin{array}{l}\text { Semi-formal, } \\
\text { quantitaive }\end{array}$ & $\begin{array}{l}\text { Bagian Pembeli (Pembelian) } \\
\text { Purchasing engineer } \\
\text { (Pembelian) }\end{array}$ \\
\hline
\end{tabular}

Tabel 3 Persyaratan Tindakan Tindak Lanjut Parker Hannifin Corporation [7]

\begin{tabular}{lc}
\hline Tindakan Yang Diperlukan & $\begin{array}{c}\text { Batas Waktu } \\
\text { (Dari notifikasi awal oleh } \\
\text { Parker) }\end{array}$ \\
\hline Pemasok harus segera mengakui penerimaan & Dalam 24 jam \\
Pemasok harus memberikan pembaruan rencana penahanan untuk & Dalam 72 jam \\
melindungi Parker selama periode waktu. Pembaruan ini harus mencakup: & \\
- Konfirmasi bahwa Pemasok telah mengidentifikasi semua produk yang & \\
dicurigai sedang dalam proses, dalam stok, dalam perjalanan, dan & \\
berpotensi di lokasi Parker mana pun dengan nomor lot, nomor kontrak & \\
Parker, dan jumlah. & \\
\hline
\end{tabular}


- Tindakan penahanan khusus tambahan yang perlu diambil oleh Pemasok dan / atau Parker.

Pemasok harus menyerahkan Laporan Tindakan Korektif lengkap (Formulir \# PH-CAR, atau peralatan) yang mengindikasikan tindakan Dalam 10 hari kerja permanen yang diambil atau akan diambil, untuk mencegah terulangnya masalah yang sama, untuk mencegah terjadinya masalah serupa, dan tanggal efektif yang berlaku.

Pada penelitian ini, analisis fokus pada sisi mutu kinerja pemasok dalam memenuhi kebutuhan industri secara lebih terperinci dan membuat rencana pengembangan dengan mengacu pada penelitian sebelumnya sehingga diharapkan tidak terjadi lagi temuan berulang dari ketidak sesuaian dengan menggunakan sistem monitoring kualitas baru yang lebih responsif. Penelitian menggunakan konsep Total Quality Management (TQM) [10][11][12], Penggunaan fishbone diagram, Failure Mode and Effect Analysis (FMEA) [6][2], dan Quality Function Deployment (QFD) diharapkan dapat meningkatkan kinerja pemasok dalam pemenuhan bahan baku yang berkualitas sesuai dengan spesifikasi perusahaan dari waktu ke waktu.

\section{METODE PENELITIAN}

Untuk mendapatkan penelitian yang komprehensif, penelitian ini menggunakan beberapa metode untuk pengambilan data sebagai berikut:

- Observasi, dilakukan secara langsung dengan mengamati proses monitoring kinerja kualitas pemasok di perusahaan manufaktur PT A, PT SIU dan PT TI, dilakukan pada saat penentuan topik dan studi pendahuluan. Ketiga perusahaan tersebut dipilih didasarkan pada skala perusahaan yang merupakan perusahaan skala menengah hingga skala besar dan memiliki jumlah pemasok lebih dari 3 jenis pemasok. Hal ini diharapkan bisa industri manufaktur secara umum. Sampel yang diambil adalah berupa dokumendokumen, baik itu formulir inspeksi, pencatatan ketidaksesuaian maupun tindakan yang diambil untuk perbaikan pada saat monitoring pemasok. Dari observasi tersebut terlihat masih terdapat pengulangan ketidaksesuaian pada ketiga perusahaan.
- Historical data, untuk melihat trend kinerja kualitas pemasok dalam penyediaan bahan baku, tindakan yang diambil jika ditemukan ketidaksesuaian dan kejadian berulang pada ketidaksesuaian yang ditemukan. Kegiatan ini dilakukan pada saat perumusan masalah penetapan tujuan penelitian, dan penentuan ruang lingkup penelitian.

- Studi literatur dengan mengkaji jurnaljurnal sebelumnya, yang dijadikan acuan untuk membuat sistem pemantauan mutu yang tepat.

- Focus Group Discussion (FGD), dilakukan untuk lebih memperdalam dan memahami kebutuhan perusahaan akan sistem monitoring kualitas untuk pemasok material. Focus Group Diagram (FGD) dilakukan pada saat pengumpulan data, pengklasifikasian ketidaksesuaian atau non conformity, dan validasi ketidaksesuaian yang terjadi. Pemilihan para ahli dan praktisi dilakukan berdasarkan pengalaman kerja di bidang rantai pasok minimal lima tahun atau lebih. Hasil dari FGD dituangkan di dalam analisis efektifitas sistem monitoring kualitas bahan baku saat ini dan rekomendasi perbaikan yang dapat dilakukan oleh perusahaan.

- Wawancara para ahli dan praktisi selain pada saat FGD, sebagai bahan pertimbangan sisi dapat diterima atau tidaknya sistem monitoring kualitas yang dibuat dan dapat diterapkan di perusahaan. Wawancara para ahli dan praktisi dilakukan pada saat menentukan persyaratan teknis atau tindak lanjut.

\section{HASIL DAN DISKUSI}

\subsection{Analisis Efektifitas Sistem Monitoring Kualitas Bahan Baku Saat Ini}

Berdasarkan literatur yang digunakan dalam penelitian ini, kualitas merupakan salah satu 
dimensi yang digunakan oleh perusahaan dalam memonitor dan menilai kinerja pemasok [1][5][9]. Lebih lanjut kualitas suatu ketidaksesuaian atau non conformity [13][14] sangat menentukan kelancaran produksi perusahaan dan kualitas suatu produk akhir dari waktu ke waktu, untuk itu perusahaan membutuhkan sistem monitoring mutu dalam memastikan kualitas bahan baku dari pemasok sesuai dengan spesifikasi yang dibutuhkan guna menunjang dan meningkatkan kelancaran produksi dan menentukan kualitas produk akhir. Pada umumnya sistem monitoring kualitas dibuat berupa prosedur kerja atau kesepakatan kerja yang digunakan departemen Quality Assurance (QA) dalam proses monitoring secara berkala.

Dalam penelitian Defect Handling in Software Metrics [15], pengelompokan tingkat kritikal suatu ketidaksesuaian dibagi menjadi tiga yaitu:

- Extreme, untuk jenis ketidaksesuaian yang membuat produk tidak dapat dipasarkan karena fungsi produk tidak dapat terpenuhi.

- Major, untuk jenis ketidaksesuaian yang membuat kualitas produk mengalami penurunan.

- Minor, untuk jenis ketidaksesuaian yang tidak memiliki potensi membuat kualitas produk menurun.

PTA merupakan perusahaan manufaktur yang telah berdiri lebih dari 10 tahun menggunakan prosedur kerja dalam memandu fungsi Material Quality Assurance (MQA) guna menghadapi ketidaksesuaian atau non conformity yang terjadi melalui pengiriman Supplier Corrective Action Request (SCAR) form ke pemasok, dan pemasok perlu mengirimkan kembali SCAR form tersebut lengkap dengan analisis akar permasalahan dan tindakan perbaikan yang dilakukan untuk menangani permasalahan tersebut. Namun berdasarkan historical data teridentifikasi beberapa non conformity berulang tetap terjadi di bulan berikutnya yang berarti sistem monitoring kualitas atau prosedur kerja yang diterapkan perusahaan belum cukup efektif untuk menangani non conformity bahan baku.

Hal yang sama juga terjadi pada PT SIU yang merupakan perusahaan distributor alat elektronika dan PT TI yang merupakan perusahaan pertambangan dimana pada PT SIU evaluasi kinerja pemasok dilakukan tiap tiga bulan menggunakan Vendor Evaluation (VE) prosedur dan untuk hasil temuan ketidaksesuaian akan dikirimkan Vendor Corrective Action Request Form (VCAR) form, sedangkan di PT TI evaluasi pemasok dilakukan setiap bulan dan setiap penerimaan barang dari pemasok, PT TI menggunakan prosedur Supplier Inspection Procedure (SIP) dan untuk temuan atas ketidaksesuaian PT TI akan mengirimkan Suppier Corrective and Preventive Action Request (SCPAR) Form. Hasil yang didapat dari ketiga perusahaan tersebut relatif sama dimana ditemukan ketidaksesuaian berulang yang harus segera ditindaklanjuti sehingga tidak terjadi lagi dimasa yang akan datang.

\subsection{Analisis Klasifikasi ketidaksesuaian Bahan Baku}

Salah satu alasan terjadinya pengulangan ketidaksesuaian atau non conformity dikarenakan penanganan setiap ketidaksesuaian menggunakan metode yang sama yaitu dengan pengisian SCAR form atau VCAR atau SCPAR tanpa memperhatikan tingkat kritikal suatu ketidaksesuaian. Oleh karena itu klasifikasi ketidaksesuaian sangat dibutuhkan dengan menggunakan fishbone diagram dan validasi menggunakan metode Failure Mode and Effect Analysis (FMEA) [6][2]. Hasil dari pengklasifikasian ketidaksesuaian bahan baku berupa tiga tipe ketidaksesuaian yaitu:

- Ketidaksesuaian extreme, yaitu ketidaksesuaian yang berpengaruh kepada beberapa hal berikut:

- Membuat proses produksi tidak berjalan.

- Tidak ada material yang tersedia.

- Target produksi tidak tercapai.

- Tidak ada produk yang bisa dipasarkan.

- Ketidaksesuaian major, yaitu ketidaksesuaian yang berpengaruh kepada beberapa hal berikut:

- Membuat proses produksi tidak berjalan lancar.

- Jumlah material untuk keperluan produksi kurang.

- Membuat produk mengalami penurunan kualitas.

- Membuat produk yang dapat dipasarkan terbatas.

- Ketidaksesuaian minor, yaitu ketidaksesuaian yang berpengaruh kepada beberapa hal berikut:

- Membuat proses traceability produksi terganggu. 
- Jumlah safety stock material di gudang berkurang.

- Membuat produk mengalami penurunan permasalahan kualitas pada area yang tidak terlihat oleh konsumen.

- Membuat pemasaran produk terganggu.

\subsection{Analisis Desain Sistem Monitoring Kualitas}

Dari hasil analisis efektifitas sistem monitoring kualitas yang ada saat ini dan hasil klasifikasi ketidaksesuaian, didapatkan data bahwa terjadinya pengulangan ketidaksesuaian terjadi pada mayoritas tipe ketidaksesuaian extreme dan major (Tabel 4). Hal ini mengindikasikan perlu adanya penanganan yang berbeda untuk kedua tipe ketidaksesuaian tersebut untuk meningkatkan efektifitas penanganan dan pencegahan ketidaksesuaian yang sama terjadi kembali.

Pada saat ini tindakan yang dilakukan jika ditemukan adanya ketidaksesuaian terangkum menjadi dua:

- Pemasok cukup mengisi form Supplier Corrective Action Request (SCAR) atau Vendor Corrective Action Request (VCAR) atau Corrective and Preventive Action Request (SCPAR), namun jika dilihat dari terjadinya ketidaksesuaian yang berulang terjadi dapat disimpulkan SCAR atau VCAR atau SCPAR tidak efektif dilakukan untuk semua tipe ketidaksesuaian.

- Jika ditemukan ketidaksesuaian yang kritikal maka fungsi Material Quality Assurance (MQA) perlu melakukan koordinasi dengan manajemen untuk selanjutnya pihak manajemen memutuskan tindakan yang akan dilakukan terhadap pemasok tersebut. Hal ini menyebabkan perlunya waktu menunggu keputusan manajemen, padahal penanganan ketidaksesuaian yang kritikal perlu dilakukan untuk mempercepat efektifitas perbaikan dalam sistem produksi perusahaan.

Berdasarkan kedua hal tersebut, maka diperlukan sistem monitoring kualitas berupa:

- Prosedur kerja memberikan beberapa alternatif tindakan berdasarkan tipe ketidaksesuaian yang telah diklasifikasikan untuk dapat meningkatkan efektifitas tindakan perbaikan

- Prosedur kerja memberikan panduan kepada fungsi Material Quality Assurance (MQA) untuk melakukan tindakan perbaikan terhadap ketidaksesuaian yang kritikal tanpa menunggu keputusan dari management sehingga dapat menghilangkan penundaan dalam pengambilan keputusan

Hasil analisis Quality Function Deployment (QFD) adalah sistem monitoring kualitas yang ada saat ini hanya cukup efektif menangani ketidaksesuaian tipe minor, sedangkan untuk tipe major dan extreme dibutuhkan penanganan yang berbeda seperti terlihat pada tabel 4 .

Tabel 4. Technical / Follow up Requirement Setiap Tipe ketidaksesuaian

\begin{tabular}{cl}
\hline Tipe NC & $\begin{array}{l}\text { Persyaratan teknis / tindak } \\
\text { lanjut }\end{array}$ \\
\hline $\begin{array}{c}\text { NC } \\
\text { Extreme }\end{array}$ & - Supplier audit \\
& - Supplier training \\
NC Major & - Membangun tim kolaboratif \\
& - Supplier visit \\
NC Minor & - SCAR + 5 Why Analysis \\
\hline
\end{tabular}

\subsection{Persyaratan Teknis dan Tindak lanjut}

Dari analisis-analisis yang sudah dilakukan, maka didapat beberapa Persyaratan teknis atau tindak lanjut yang bisa dilakukan untuk menangani ketidaksesuaian supaya lebih efektif, yaitu:

- Audit Pemasok, dalam hal ini perusahaan melakukan audit ke pemasok untuk melihat sistem mutu yang berjalan di pemasok. Audit mencakup sistem mutu di produksi, monitoring kualitas dari material setelah produksi, penyimpanan di gudang, sistem pengiriman material dari pemasok ke perusahaan, dan sistem pelacakan. Sistem audit menggunakan ISO 9001:2015 [16] [17] yang mengatur sistem manajemen kualitas.

- Pelatihan untuk pemasok, dalam hal ini perusahaan memberikan pelatihan kepada pemasok mengenai pentingnya menjaga dan meningkatkan kualitas produk dan sistem yang ada di pemasok untuk mencegah terjadinya suatu non conformity di perusahaan

- Membangun kerjasama tim, dalam hal ini perwakilan dari pemasok dan perusahaan membuat suatu team untuk menyelesaikan suatu ketidaksesuaian. Perwakilan baik dari pemasok maupun perusahaan adalah para ahli di bidangnya masing-masing.

- Kunjungan ke pemasok, dalam hal ini perusahaan berkunjung ke pemasok untuk mendiskusikan beberapa hal yang terkait dengan ketidaksesuaian dan observasi di 
bagian tertentu di area yang berpotensi menimbulkan ketidaksesuaian.

- Komunikasi secara teratur, dalam hal ini pemasok dan perusahaan melakukan komunikasi secara reguler untuk melihat perkembangan penanganan suatu ketidaksesuaian yang terjadi. Komunikasi dapat dilakukan melalui rapat koordinasi antara pemasok dan perusahaan, bisa juga melalui media elektronik baik itu email, telepon ataupun media lainnya atau bisa juga melalui surat tertulis kepada pemasok guna memastikan ketidaksesuaikan yang ditemui dapat segera diatasi dengan baik dan benar dan tidak terulang lagi di masa yang akan datang yang mana dapat mengakibatkan kerugian baik secara materi maupun non materi bagi perusahaan.

- Supplier Corrective Action Request (SCAR) form atau Supplier Corrective Action Request (SCAR) form atau Vendor Corrective Action Request (VCAR) atau Corrective and Preventive Action Request (SCPAR) form + 5 Why analysis, dalam hal ini pemasok melakukan analisis secara mandiri dengan menggunakan analisis 5 Why terhadap kemungkinan terjadinya ketidaksesuaian, yang didokumentasikan menggunakan SCAR form dan dikirimkan ke perusahaan sebagai bukti tindakan pencegahan dan perbaikan telah dilakukan di pihak pemasok.

\section{KESIMPULAN}

Sisi kritikal suatu ketidaksesuaian untuk mengendalikan dan meningkatkan kinerja pemasok dalam memasok bahan baku yang berkualitas harus dipertimbangkan dan dibuat suatu sistem monitoring kualitas yang lebih responsif terhadap semua ketidaksesuaian yang mungkin terjadi. Desain sistem monitoring kualitas yang lebih responsif dan mempertimbangkan sisi kritikal suatu ketidaksesuaian untuk mengendalikan dan meningkatkan kinerja pemasok dalam memasok bahan baku yang berkualitas harus dilakukan agar kejadian berulang pada ketidaksesuaian tidak lagi terjadi. Penanganan setiap tipe ketidaksesuaian yang berbeda mengindikasikan bahwa kualitas perlu dilihat secara total atau keseluruhan dengan fokus pada kepuasan konsumen (customer focus)[18][19][20]. Melibatkan beberapa fungsi perusahaan dan pemasok (total participation) untuk proses monitoring dan peningkatan kualitas secara berkelanjutan (continual improvement).

Hasil dari penelitian ini belum membahas detail dari setiap persyaratan teknis dan tindak lanjut yang digunakan untuk penanganan suatu ketidaksesuaian. Untuk penelitian selanjutnya, direkomendasikan untuk memformulasikan setiap detail technical atau follow up requirement untuk lebih memberikan panduan kepada perusahaan dan meningkatkan efektifitas penanganan suatu ketidaksesuaian material.

\section{DAFTAR PUSTAKA}

[1] A. Nair, J. Jayaram, and A. Das, "Strategic purchasing participation, supplier selection, supplier evaluation and purchasing performance," Int. J. Prod. Res., vol. 53, no. 20, pp. 6263-6278, Oct. 2015. Available at: doi 10.1080/00207543.2015.1047983

[2] H. Safari, Z. Faraji, and S. Majidian, "Identifying and evaluating enterprise architecture risks using FMEA and fuzzy VIKOR," J. Intell. Manuf., vol. 27, no. 2, pp. 475-486, 2016. Available at: doi 10.1007/s10845-014-0880-0

[3] R. Chavhan, "Supplier Developmet: Theories and Practices," IOSR J. Mech. Civ. Eng., vol. 3, no. 3, pp. 37-51, 2012. Available at: doi E0333751

[4] F. Peter and G. Lars-Erik, "Evaluation of Supplier Performance," Dep. Ind. Mark. Chalmers Univ. Technol. Gothenburg, Sweden., 2012._Available at: doi 14572345

[5] A. Ulutas, N. Shukla, S. Kiridena, and P. Gibson, "A utility-driven approach to supplier evaluation and selection: empirical validation of an integrated solution framework," Int. J. Prod. Res., vol. 54, no. 5, pp. 1554-1567, Mar. 2016. Available at: doi 282749261

[6] H. Ae, J. Won, Y. Yun, and H. Moo, "FMEA에서 고장 심각도의 탐지시간에 따른 위험성 평가 Risk Evaluation in FMEA when the Failure Severity Depends on the Detection Time," vol. 31, no. 4, pp. 136142, 2016. Available at: https://www.jksqm.org/m/makeCookie.php ?url=/m/journal/view.php?number=774

[7] P. Hannifin, Supplier Quality Requirements 
Manual. 2012. Available at: https://www.parker.com/parkerimages/Par ker.com/About\%20Us/Literature/PHSQRM.pdf (Diakses : 2 Oktober 2019).

[8] L. O. Kiran J. Desai, Mayur S. Desai, "Supply Chain Risk Management Framework: A Fishbone Analysis Approach." 2015. Available at: http://search.proquest.com/openview/012 72a5eaf64dbc8032d73fa303cbc8d/1?pqorigsite $=$ gscholar $\& \mathrm{cbl}=40946$

[9] K. Zimmer, M. Fröhling, and F. Schultmann, "Sustainable supplier management - a review of models supporting sustainable supplier selection, monitoring and development," Int. J. Prod. Res., vol. 54, no. 5, pp. 1412-1442, Mar. 2016._Available at: doi $\underline{10.1080 / 00207543.2015 .1079340}$

[10] T. Edition, Total Quality. 2015 ._Available at: Google Document

[11] I. A. Elshaer, "Direct effects of quality management on competitive advantage," 2016._Available at: doi $\underline{382808}$

[12] D. P. Kafetzopoulos, E. L. Psomas, and K. D. Gotzamani, "The impact of quality management systems on the performance of manufacturing firms," vol. 32, no. 4, pp. 381-399, 2015. Available at: doi 10.1108/IJQRM-11-2013-0186

[13] A. Chiarini, "Effect of ISO 9001 nonconformity process on cost of poor quality in capital-intensive sectors," 2015. Available at: doi 10.1108/IJQRM-03-2013$\underline{0041}$

[14] A. Giorgetti, C. Cavallini, A. Ciappi, G. Arcidiacono, and P. Citti, "A Holistic Model for the Proactive Reduction of Nonconformities within New Industrial Technologies," no. February 2018, pp. 10 15, 2017._Available at: doi 318270952

[15] A. Mittal and S. kumar Dubey, "Defect handling in software metrics," Int. J. Adv. Res. Comput. Commun. Eng., vol. 1, no. 3, pp. 167-170, 2012._Available at: doi $\underline{10.1 .1 .220 .2559}$

[16] A. Chiarini, "Risk-based thinking according to ISO 9001: 2015 standard and the risk sources European manufacturing SMEs intend to manage," vol. 310, 2016. Available at: doi 10.1108/TQM-04-2016$\underline{0038}$

[17] P. Domingues, "Iso 9001:2015 editionmanagement, quality and value," vol. 11, no. 1, pp. 149-158, 2015._Available at: doi $\underline{10400.22 / 9677}$

[18] N. Carolina and P. Hong, "Post-purchase shipping and customer service experiences in online shopping and their impact on customer satisfaction An empirical study with comparison," 2018. Available at: doi 10.1108/APJML-04-2017$\underline{0071}$

[19] S. Sreejesh, "Examining the roles played by a store satisfaction-love framework in shaping the influence of store loyalty programs," vol. 39, no. 8, pp. 879-898, 2015. Available at: doi 10.1108/MRR-062014-0150

[20] D. W. Fernandes, R. G. Moori, P. De Pósgraduação, A. De Empresas, U. P. Mackenzie, and S. Paulo, "Logistic service quality as a mediator between logistics capabilities and customer satisfaction," vol. 25 , no. 4 , pp. 358-372, 2018. Available at: doi 10.1108/REGE-01-2018-0015

\section{Author Biography}

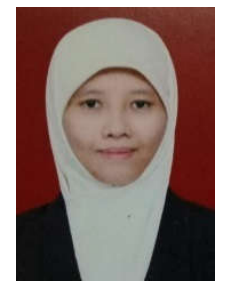

Dahliyah Hayati, S.T., M.T. merupakan Dosen Asisten Ahli di Politeknik APP Jakarta dengan latar belakang pendidikan (S1) Teknik Pertambangan dan (S2) Teknik Industri Universitas Indonesia. 